\title{
Integrative Planning of Post-suburban Growth in the Glatt Valley (Switzerland)
}

\author{
Constance Carr $^{1}$ - Evan McDonough ${ }^{1}$
}

Received: 25 September 2015 / Accepted: 26 May 2016 / Published online: 6 June 2016

(c) Springer-Verlag Berlin Heidelberg 2016

\begin{abstract}
This paper addresses conditions of post-suburban urbanisation. Our empirical base is drawn from observations of integration initiatives in the region of the Glatt Valley, a rather undefined area extending from the City of Zurich towards the airport and spreading over a number of small municipalities. Under growth pressure, municipalities are coordinating housing, transportation, and economic activity, and this is generating new post-suburban forms. To understand these processes, qualitative methods were used, relevant documents surveyed, and conversational interviews with actors in the area conducted. A process of infrastructure consolidation was observed, which moved towards integrating functional pathways and optimising capital accumulation, and attracting and catering for business development and high-income earners. To date, the region has proved to be diverse and dynamic, while also furthering certain modes of fragmentation and social stratification. The results reveal post-suburban forms that are place specific and path dependent insofar as they are driven by particular arrangements of governance that emphasise a certain mode of integrative planning. This form of post-suburban growth is also producing new forms of fragmentation.
\end{abstract}

Keywords Post-suburban $\cdot$ Switzerland $\cdot$ Zurich $\cdot$ Glatt Valley · Integrative planning · Governance

Dr. Constance Carr

constance.carr@uni.lu

Evan McDonough

evan.mcdonough@uni.lu

1 Institute of Geography and Spatial Planning, University of Luxembourg, 11, Porte des Sciences, 4366 Esch-Belval, Luxembourg

\section{Integrative Planung als post-suburbane Entwicklungsstrategie im Glattal (Schweiz)}

Zusammenfassung Dieser Beitrag befasst sich mit Bedingungen der post-suburbanen Entwicklung in der Schweiz. Die empirische Basis bilden Beobachtungen von Raumplanungs- und Governancepraktiken im Glattal, einem nicht klar abzugrenzenden Gebiet, welches sich von der Stadt Zürich bis jenseits des Flughafens erstreckt und viele kleine Gemeinden umfasst. Unter Wachstumsdruck koordinieren die Gemeinden den Wohnungsbau, die Verkehrsplanung und die wirtschaftliche Entwicklung. Somit entstehen neue post-suburbane Räume. Diese Urbanisierungsprozesse in der Region wurden mittels qualitativer Maßnahmen analysiert. Relevante Dokumente wurden ausgewertet und Interviews mit Akteuren der Region durchgeführt. Dabei konnte ein Prozess der Konsolidierung von Infrastrukturen zur Optimierung der Kapitalakkumulation beobachtet werden. Dieser fördert die Anziehung von Betrieben, pflegt die wirtschaftliche Entwicklung und die Ansiedlung einkommensstarker Haushalte. Bis dato entfaltet sich die Region vielfältig und dynamisch, fördert aber auch Formen der Fragmentierung und der sozialen Schichtung. Die Ergebnisse zeigen ebenso post-suburbane Formen, die ortsspezifisch sind und welche sich durch historisch gegebene Governancestrukturen und damit verbundene spezifische Modelle der integrativen Raumplanung ergeben. Diese Form von postsuburbanem Wachstum produziert neue Muster der Fragmentierung.

Schlüsselwörter Post-suburban - Schweiz - Zürich · Glattal · integrative Planung · Governance 


\section{Introduction}

There is a vast literature addressing and explaining the various suburban forms that convincingly deconstructs the oldfashioned 'Leave it to Beaver' notion of suburban places being simply dormitory landscapes of white single-family housing and reveals how suburbs have diversified over the last few decades. In fact, a number of scholars have eradicated the notion that such places are sub-urb altogether. These scholars (Burdack/Hesse 2007; Young/Keil 2010; Phelps/Wood/Valler 2010; Phelps/Wood 2011) have undertaken important work, revealing that processes of urbanisation and suburbanisation are changing so that the ways suburbs are built, lived, and functionalised can now be conceptualised as processes of post-suburbanisation. Yet, so far much of this literature has focused primarily on North America. Exploring post-suburbanisation beyond the Anglo-American sphere is thus one of the objects of this paper, which aims to address post-suburban socio-political and economic processes taking place in Switzerland and to assess how these reflect contextual place-specific and pathdependent modes of governance and land-use regulation. The research focuses on a specific area of the greater Zurich region: the Glatt Valley. This is a region that in the past has been viewed as suburban Zurich but is now a place of employment and inward commuting trips associated with ever-increasing economic activity. It is also an area where state-driven infrastructure projects and integrative planning practices have been instrumental in its transformation.

This paper shows how the integrative planning practices of local governance are driving this trajectory of development in the Glatt Valley, revealing that on-going processes have produced a built environment that is distinct from that which might be expected in either the traditional European city or the classic post-war suburb. The argument is structured as follows. First, the literatures are reviewed, beginning with the current literature on post-suburbs and followed by a short discussion on integrative planning and densification, as these are guiding principles in Swiss planning circles. Next, the object and methods are described. This is followed up with a review of the planning practices that drive the ongoing post-suburbanisation process, focusing on available planning instruments and an analysis of local governance structures. Lastly, the contribution of this paper to the international literature is explained.

\section{Literature}

The arguments delivered in this paper are situated at the nexus of two streams of scholarly literature: post-suburban urbanisation and the practice of integrative planning. At first glance, the notion of post-suburbs and integrated planning may seem unrelated: the former addresses morphologies, structures and functions of new patterns of urban space where sectors may or may not relate to their surroundings, while the latter suggests that a certain balance is achievable as a result of certain recipes for planning. Both are buttressed by their own scholarly discourses. These two strands are addressed here because this research has found that the strategic practice of integrated planning is, however surprisingly, a driving force guiding development in this case study of a European post-suburban built environment.

\subsection{From Suburban to Post-Suburban}

The archetypal imaginary of the 'suburb' still often recalls post-war Levittown-modelled 'sprawl', the easily recognisable North American model of homogenous, lowdensity, car-dependent, self-isolating residential corporate subdivisions built on greenfields (Jackson 1985; Fishman 1987; Peck 2011). In planning theory and urban studies, this settlement type is often considered the antithesis to the ideal of diverse, compact, walkable, mixed-use and purportedly more sustainable city centres, a revered built form associated with continental Europe especially (Jacobs 1961; Beatley 2000). A large vocabulary exists to describe such spaces, including "Zwischenstadt" (Sieverts 2003), "postmetropolis" (Soja 2000), "Netzstadt" (Oswald/ Baccin/Michaeli 2003), a "middle landscape" between the urban and the rural (Rowe ), the "100-mile city" (Sudjic 1992), "the next slum" (Hesse 2010), urban subcentres, multinucleated metropolitan regions and centreless cities (Parker 2004: 83). While the diversity of suburbs may be widely understood, the term 'suburban' still often takes on a pejorative meaning as it continues to be frequently juxtaposed to its supposed opposite, the idealised city, which is also an out-dated term and arguably "an ideological representation of urbanization processes" despite "the explosion of the city form" (Wachsmuth 2014: 75). Moving away from this classic image, these attempts aimed to refocus the lens on suburbs to more accurately assess their function, importance, and sociopolitical economic geography. Alluding to the declining usefulness of the term 'suburb', Fishman (1987: 29) asked, "[A]s both core and periphery are swallowed up in seemingly endless multicentered regions, where can one find suburbia?" Although certain discourses within urbanism may still employ the trope of an essential binary between urban and suburban, convincing empirical evidence suggests that these generalising definitions have lost relevance and usefulness with regards to understanding, and finding planning solutions for, the contemporary city-region.

Kling, Olin and Poster (1995) helpfully introduced the term 'postsuburban' to imply a break from the previous sub- 
urban model. Here contemporary growth still produces new residential spaces outside of the central city, but this trajectory also includes increasingly diverse functions, including business districts, logistics centres, airport-oriented growth, and increasingly dense housing as well. This work suggested that such spaces are neither subordinate to nor necessarily dependent on 'the city', as 'sub-urban' suggests. Rather, contemporary post-suburban spaces are central to the growth and development of the urban region in their own right. Thus, the concept of 'post-suburbia' has gained momentum with ground-breaking empirical research and critical urban theory on both sides of the Atlantic (Burdack/ Hesse 2007; Young/Keil 2010; Phelps/Wood 2011; Mace 2013; Charmes/Keil 2015). This work has illustrated that the suburban paradigm is not only out-dated, but is an altogether ill-suited metaphorical concept for urban growth. Here, the work of Phelps, Wood and Valler (2010) should be stressed as well. They are clear that 'post-suburban' is not, in itself, another essentialist category; rather it is a lens that offers new dimensions to understand and compare new urban spaces.

Although much of this literature has focused on North American and British urbanisms, growth on the urban periphery has also been exhibited in continental Europe. In the 1990 s, Lehrer (1994: 191), for example, observed development in areas that spanned across the Swiss "ribbon city" that was said to stretch from St. Gallen, over Winterthur and Zurich, and westwards over Bern towards Geneva. A new form of urbanisation had emerged in Europe: "a city without clear boundaries and a lack of center" (Lehrer 1994: 203), and further, these suburbs were economic powerhouses and centres of employment (Lehrer 1994: 188). In some ways the urbanisation along the periphery here resembled a "reconstitution of outer cities", consistent with Soja's (2011) conception of the Los Angeles model of dispersed urban-regional growth, as well as Fishman's "technoburb" (1987) and Garreau's "edge city" (1991), as both emphasise concentrations of employment development (oriented around the technology and service sectors) outside of central cities. Many of these elements can still be viewed in the Glatt Valley, an area that is emerging as a dynamic, multi-faceted, and complex landscape of activity beyond the limits of, and increasingly independent from, the central city.

Likewise, Lehrer (1994) also observed that Swiss development was promoted by the state-managed expansion of the railway, perhaps unlike many North American suburbs. The unique political challenges to urban governance in post-suburbs more broadly has also received close attention (Phelps/Wood 2011; Charmes/Keil 2015). This paper contributes to this important work by focusing on the process of governance that drives post-suburban forms in the Glatt Valley, confirming that post-suburban forms in Switzerland are not produced by an evacuation of the state. Rather, the process is guided by a set of deliberate decisions, in a certain context of "blended scales" (Affolderbach/Carr 2016) of small state governance, and by particular planning policy frameworks.

\subsection{Regional Integration and Local Fragmentation}

Particular orthodoxies within the local governance structures in the Canton of Zurich can be understood as driving urbanisation in the Glatt Valley. Specifically, the policy of integrative planning seeks to attract development to the Glatt Valley rather than the central city, and to coordinate activities related to Switzerland's main airport with municipal development in the surroundings, promoting the re-centralisation of economies beyond the City of Zurich. These strategies have been successful in challenging the primacy of the central city as the 'economic engine' of the city-region. However, this shift in the trajectory of urban growth has resulted in rather chaotic growth patterns in the Glatt Valley.

It is thus useful to recall the literature that critically examines integrated planning as a planning practice. Graham/ Marvin (2001: 122) connected the "sprawling and 'supermodern' urban landscapes" which blurred the distinction between the urban and periphery to theories of "the collapse of the modernist integrated ideal" and the ominous trajectory of "splintering urbanism". They showed that urbanregional planning and the extension of urban infrastructure can be part of a trajectory of urbanisation that promotes the fragmentation of the city-region through the selective integration and exclusion of local populations. In this respect, transport infrastructure may be seen as representative of the fragmenting tendencies and contradictory logics of neoliberal urban governance in large city-regions (Hesse/ Carr 2013, Storper 2014).

Meanwhile, a new paradigm of planning and territorial development has emerged in Europe in recent years: integrated spatial planning (Stead/Meijers 2009; Allmendinger 2009; Carr/Becker/Evrard et al. 2015). It has taken on particular velocity since the Leipzig Charta on Sustainable European Cities - which Switzerland has committed to where it was a central concept, and it now underlies other EU planning programmes such as the Territorial Agenda promoting territorial cohesion (Carr/Becker/Evrard et al. 2015). Characterised as comprehensive, aggregated topically, and all-encompassing (Stead/Meijers 2009), the goal of integrated planning is:

- to overcome artificial organisational boundaries,

- to tolerate a significant degree of uncertainty and probability in the policy-making process, 
- to interact closely with stakeholders and citizens; and, significantly,

- to engage in flexible, creative and systemic thinking which is "holistic" rather than linear or partial in character.

(Givoni/MacMillen/Banister et al. 2013: 2).

Integrated planning aims to provide coherence across space (e.g. the city-region) and time, and claims innovativeness by going beyond the confines of certain sectors, and moving away from particulate, rigid, and out-moded land-use practices of town or city planning towards a rigorous, cross-sector approach that addresses broader framework conditions, involving actors from wider networks.

We have been critical of integrative practices elsewhere (Hesse/Carr 2013; Carr/McDonough/Telaar 2015; Carr/ Becker/Evrard et al. 2015), but there are several remarks to reiterate again here. First, these plans are often framed by neoliberal agendas, as Allmendinger (2009: 2547) explains. Second, the idea that planners can and will achieve the right balance of the right problems in the right ways with the right instruments is a kind of hubris, whereby planners really believe they can promise "a final state of blue-printed harmony" (Faludi 1970: 3). Third, the ability to assert certain discourses and to enact a certain spatial material change is an exercise in power (Carr 2015). Fourth, integrated spatial planning often claims but does not deliver a realistic solution, particularly with regards to addressing socio-economic exclusion (Enright 2013). The integrated approach is, thus, limited in its conception as well as its ability to foster real long-term, meaningful change. Our research on the Glatt Valley also revealed problems of fragmentation and unintended consequences.

\section{Object of Study and Methods}

The object of this research was the Glatt Valley. It can be located on a map, spanning roughly across the 11th and 12th northern districts of the City of Zurich and spreading northeast towards Zurich Airport, encompassing a number of neighbouring municipalities located on or near the Glatt River (Fig. 1). However, there is no precise territory, so pinning down the limits and boundaries of the area is rather difficult.

The municipalities of the Glatt Valley belong to an area in Switzerland that is usually referred to as the Zurich agglomeration, and this has financial implications (as explained below). This requires some explanation, however, because in the Swiss context, 'agglomeration' has ambiguous meanings. In the classical sense, agglomerations are understood as being regions oriented around or towards a particular city, and are often identified as spaces with a certain minimum of population density, commercial de- velopment, and traffic level (Annaheim 1969: 99). For many years, too, these places were seen as problem areas that represented morally incorrect development devouring the pristine Swiss landscape (Heye/Leuthold 2006; Daum/ Schneeberger 2013). The 'Agglo' became a kind of derogative term, perhaps not unlike 'the burbs' in English. Recent accounts explain agglomerations as areas that have upset the dominance of Swiss central cities and have constituted metropolitan regional spaces with which classical central cities, such as Zurich, are now at least interdependent if not competitive (Koll-Schretzenmayr/Schmid 2003). The Agglo is no longer the backyard of central cities. Rather, single municipalities or small coalitions of municipalities position themselves on the global market and compete with the central city (Koll-Schretzenmayr/Schmid 2003: 13). These qualities apply to the Glatt Valley.

Although the Glatt Valley has no specific borders, the area has been referred to as the Glatt City (Glattal-Stadt). Some commentators have also observed, too, that this is a kind of identity formation and an attempt to selfprofile the region differentiating it from Zurich (KollSchretzenmayr/Schmid 2003). A key organisation in the area, Flughafenregion ('Airport Region' formerly known as 'Glow.das Glattal'), promotes this concept, and key member municipalities include Dübendorf, Wallisellen, Bassersdorf, Opfikon, Kloten, and Rümlang. Still, functional spaces and flows blur the rigid boundaries suggested by the notion of a cohesive 'Glatt City'. The Glatt Valley is fittingly perceived as a collection of colliding as well as overlapping spaces of negotiation, and engulfing a complex set of institutions that have varying sets of responsibility and jurisdictional arrangements (Thierstein/ Kruse/Glanzmann et al. 2006).

The area is currently being transformed under distinct growth pressure. The Glatt Valley is one of the three major axes - the other two being northward along the Limmat River, and southwards along the west coast of Lake Zurich towards the Canton of Schwyz - well positioned to harness the spillover effects of growth pressure in Zurich. And indeed, as housing prices in the City of Zurich have continued to squeeze out the middle and lower classes, the Glatt Valley has become an attractive location. However, as Glatt municipalities successfully attract new businesses to the area, the number of commuters travelling to the Glatt to work is rising. Some municipalities such as Opfikon and Kloten meanwhile receive more commuters on a daily basis than they have inhabitants (Tab. 1). These developments have generated pressures on administrative and infrastructural systems as municipalities - which are sparsely staffed, characterised by very close-knit relations between and among administrators, politicians, respective constituents and members of the private sector, and function on systems of 'militia government' - are forced to co-ordinate beyond traditional and 
Fig. 1 The area of the Glatt Valley within the Canton of Zurich, (Map by Malte Helfer, Institute of Geography and Spatial Planning, University of Luxembourg)

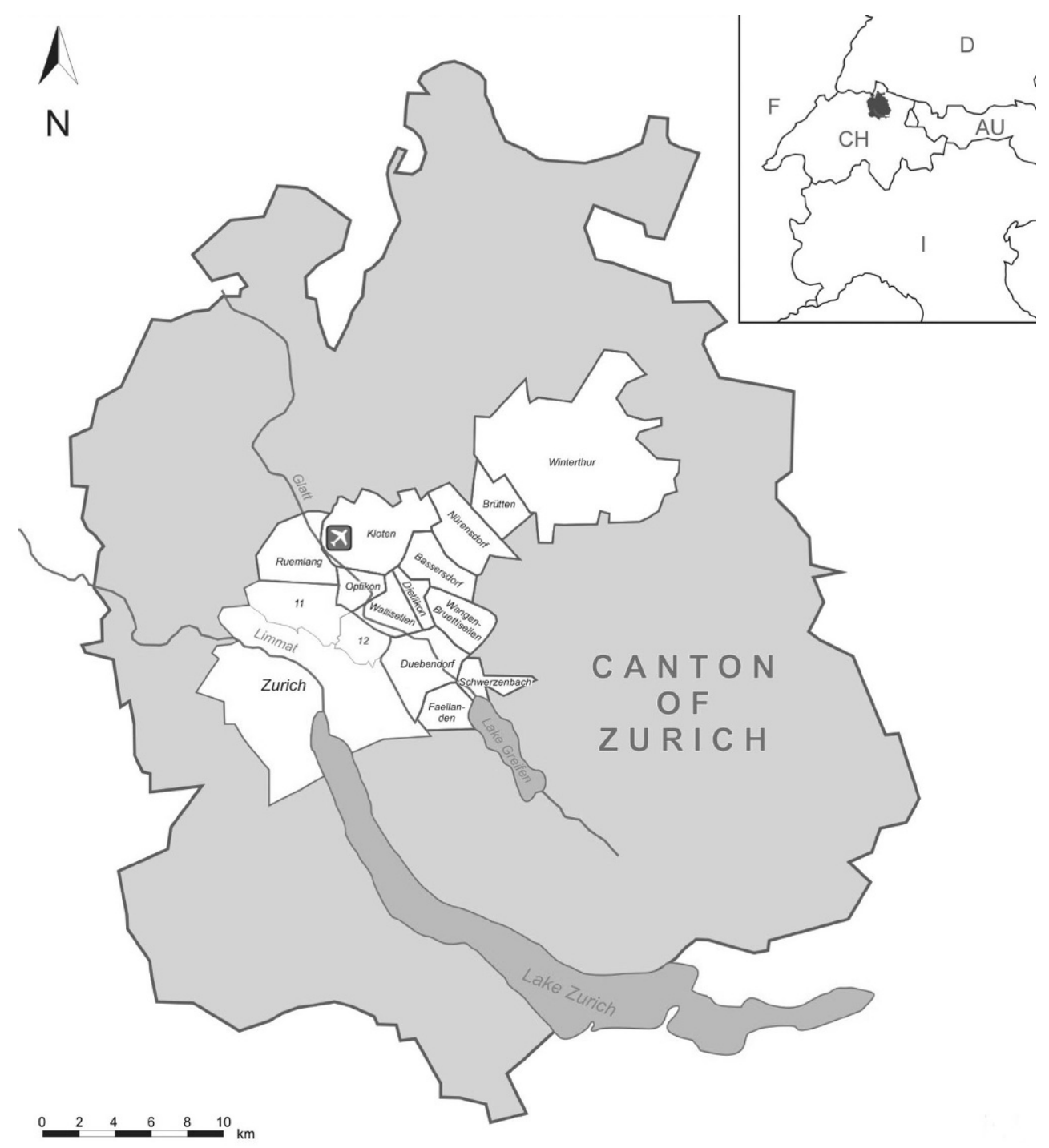

administrative borders to drive a regional growth that is less dependent on Zurich.

Qualitative methods were employed to investigate the new urban forms emerging in the Glatt Valley and the practices driving them. This began as a general document survey, pinpointing and scanning documents, websites, magazines and newspapers. This provided an overview of the problems facing the region and the kinds of discussions being vocalised. It was also possible to uncover some of the main actors and institutions engaging in such discourses. Next, after establishing this general overview, the area was toured, public presentations and community meetings were attended, and informal conversations with local scholars were held. These included events organised by the Swiss Federal Institute of Technology in Zurich (ETH), public transit authorities, and individual municipalities. Here again, further important actors could be identified who could be then approached for an interview.
In the end, 25 conversational interviews were conducted with planners, governmental officials (at municipal, cantonal, and regional levels), real estate agents, architects, urbanists, and neighbourhood associations in the area. In this endeavour, conversations were held with a cross-section of actors in the Glatt Valley, including a number of governing officials from Zurich's northern districts: Wallisellen, Dübendorf, Wangen-Brüttisellen, Bassersdorf, Opfikon, Kloten, Dietlikon, and Winterthur. Generally, participants were asked about their perceptions concerning the overall trajectory of development in the Glatt Valley. They were requested to identify key problems or challenges associated with this trajectory, as well as to comment on their capacities to address these issues, with reference to the palate of planning instruments available to co-ordinate any desired development. They were also asked about their perceptions of the role of local democracy and public participation, as well as the quality of inter-municipal or public-private cooperation in such processes of urban change. Through these 
Tab. 1 Growth statistics and land use in member municipalities of the Flughafenregion (Source: Kanton Zürich (2015), Flughafenregion Zürich (2013: 17))

\begin{tabular}{llll}
\hline Municipality & $\begin{array}{l}\text { Population (Number of } \\
\text { Inhabitants) } 2014\end{array}$ & $\begin{array}{l}\text { Percentage growth since } \\
1996(\%)\end{array}$ & Number of workplaces housed by municipality \\
\hline Bassersdorf & 11,500 & 39 & 5,000 \\
Dietlikon & 7,500 & 23 & 6,000 \\
Kloten & 18,500 & 12 & 34,000 \\
Opfikon & 17,000 & 35 & 18,000 \\
Wallisellen & 15,500 & 26 & 14,000 \\
Rümlang & 7,500 & 31 & 6,000 \\
Dübendorf & 26,500 & 21 & 18,000 \\
Wangen-Brüttisellen & 8,000 & 31 & 5,000 \\
\hline
\end{tabular}

conversations it was possible to uncover the various positions taken by different actors, and to discover the various sectors of urban development that took priority and why. Interviews were recorded, transcribed and then coded using MAXQDA software. This textual data constituted the project's primary database, which the research team could refer back to during write-ups in the later phases of the research.

This method was chosen because the research did not seek to find best practices or recipes of good development. Rather, the objective was to find out how local decisionmakers perceived their problems and how they viewed challenges and obstacles. This approach was inspired by the 'interpretative institutionalism' framework (Bevir/Rhodes 2004; Bevir/Rhodes 2006; Krueger/Gibbs 2012) that aims to decipher the norms and beliefs that determine the attitudes of professionals toward their problems, their understanding of possible solutions, and how they interpret the dilemmas of implementation. It is a method that helps to uncover the contextual nuances specific to places such as the Glatt Valley.

\section{Planning Practices Driving Post- Suburbanisation in the Glatt Valley}

The Glatt Valley has undergone attempts to consolidate infrastructure towards optimising capital accumulation along particular axes. Housing, transportation, and business development were key areas that needed to be integrated for success. This is coordinated, albeit unevenly, by certain place-specific systems of governance, institutional arrangements, and sets of planning instruments.

\subsection{Swiss Spatial Planning}

Understanding land-use policy is central to interpreting urban transformation in the Glatt Valley. Here there is a plethora of guidelines, programmes, and regulations to follow, many of which are available at the websites of the Swiss Federal Office for Spatial Development (Bundesamt für Raumentwicklung) (ARE 2015), the Canton of Zurich, or the City of Zurich and Glatt municipalities.

First and foremost, decision-makers must adhere to the legally binding instruments that concern spatial planning. At the federal level, there is the Spatial Planning Law of 1979 (Raumplanungsgesetz, $R P G)^{1}$ that sets out the legal framework for land use across Switzerland, with the goal of ensuring:

- efficient use of land, while protecting soil, water, air, and forest,

- settlement structures are built on pre-existing building sites,

- compact design of new settlements,

- enough space is available for economic activity,

- there are enough resources for the nation.

The law is occasionally revised, most recently in response to political pressure by the so-called Landscapes Initiative (Landschaftsinitiative) to restrict the further allocation of building lots beyond the existing boundaries of building zones. Next, Swiss municipalities are bound by their respective cantonal and regional regulations. The municipalities of the Glatt Valley are bound by policies of the Canton of Zurich; thereby the Official Cantonal Spatial Plan (kantonaler Richtplan) is the pertinent legally binding document with respect to spatial planning. Revised roughly every ten years (Kanton Zürich 2014), and adhering to upper-level directives, it sets general land use and minimum levels of development to be addressed by the lower-level regional development plans (regionale Richtpläne) across the Canton (Kanton Zürich 2015). The plan aims to present a broad picture of land-use development across the canton, including issues of settlement, landscape, transportation, waste management, and public infrastructure, while targeting nei-

\footnotetext{
${ }^{1}$ https://www.admin.ch/opc/de/classified-compilation/19790171/index.
} html (22.04.2016). 
ther particular plots of land nor specific landowners (Kanton Zürich 2015: 3).

The regional development plans, in turn, specify the development trajectory more precisely, defining the structure of settlement areas, usages for particular pieces of land, target levels of densification, the degree to which a particular area may transform, and the locations of productive, recreational and natural areas (Kanton Zürich 2015: 3). These plans are organised by 12 regional bodies across the canton. For the Glatt Valley, the relevant body is the Zurich Planning Group Glattal (Züricher Planungsgruppe Glattal, ZPG). With the assistance of the Glatt Regional Spatial Concept (RegioROK Glattal), it develops the legally binding Regional Development Plan (Regionaler Richtplan) together with representatives from the municipalities within the area of jurisdiction. In addition to the eight member municipalities of the Flughafenregion, these include Maur, Greifensee, Fällenden, Schwerzenbach, Volketswil, and Nürensdorf. The regional plans complement the cantonal plans, defining how overarching strategies for urban development should be implemented. This includes defining transport routes, and building densities, and coordinating the needs of development and infrastructure.

Examination of the cantonal and regional spatial plans immediately reveals that they are set up in nested hierarchies reflecting the nested jurisdictions. The top priorities of such plans are clearly 'inward settlement development' (Siedlungsentwicklung nach innen), densification (Verdichtung) within existing building perimeters and the intensification of development on existing building land or previously derelict areas (Verdichtung nach innen). Within these framework specifications, the municipalities determine the finer zoning and implementation details. It is also important to stress that each plan must be approved by the respective overarching authorities. This vertical back and forth is referred to as the counter-current principle (Gegenstromprinzip).

In addition to the legal framework, there are also nonbinding guidelines that planning authorities can draw upon, such as the spatial planning programmes orchestrated by the ARE - the branch of the federal administration responsible for spatial planning. These programmes are informed by ideas published in an orientation document (Raumkonzept Schweiz) (Schweizerischer Bundesrat 2012) that echoes the values outlined in the Spatial Planning Law, and identifies the kinds of areas to be addressed: alpine regions in the south, polycentric system of small and mid-size city-regions in the north, the tourism industry, transport infrastructure, and the densification of built areas. It also addresses suburban growth.

In suburban areas settlement structures, recreational areas, and agricultural areas are to be holistically designed. As in other areas, the settlement structures beyond the perimeters of the building zones are to be limited, and resources within the perimeters have to be mobilised, thus increasing the value of existing built-up areas. Furthermore, the quality of existing urban and ecological systems and public spaces is to be improved. Their attractiveness for housing, business and services should be increased. Natural and recreational spaces are to be networked and organised across municipal borders (Schweizerischer Bundesrat 2012: 45).

The federal level has little leeway to direct or dictate how these goals are to be met, as the legal framework with regards to spatial planning is already in place. Financial instruments exist, however, to encourage specific developments. Financed by Infrastructure Funds, the Agglomeration Programme is such an instrument. Lower-level governing institutions design land-use arrangements and if the federal level deems them within the objectives of the programme, it can allocate funds (Koll-Schretzenmayr/Schmid 2003; ARE 2015). So far, the funds have been used for transport infrastructure, for instance for the newly completed tram in the Glatt Valley (Schweizerischer Bundesrat 2014).

\subsection{Glatt Valley Governance}

There are several features that characterise governance in the Glatt Valley. Firstly, it is steered by a collection of relatively autonomous municipalities. Secondly, they operate along the tenets of direct democracy, but also, and thirdly, through informal networks of actor coalitions often involving private partners.

Municipalities of the Glatt Valley decide how to manage current socio-economic conditions. Typically, because the municipalities themselves are small (see population counts in Tab. 1) the municipal administrations are sparsely staffed. This stands in stark contrast to Zurich, Switzerland's largest city, with its district offices and hundreds of civil servants. A comparison of those employed in urban development is impressive: while the City of Zurich has upwards of 25 persons in that single domain, the municipalities of the Glatt might employ one. Municipalities are in charge of the provision of schools, transport infrastructure, policing and security services, recreation centres, administration of social services, ecosystems management, elections, management of tax revenue, and allocation of building land - within the constraints of procedures passed at either the cantonal or the federal level.

All levels of government operate with direct democracy and all plans and changes to the law are voted upon by residents of the respective jurisdiction. This provides for a high degree of transparency. Municipal budgets, for example, are often published online. And, when projects are approved - a process that may take a long time - the financing is 
set as well, allowing projects to move ahead with speed. One interviewee (Municipal Representative, March 2014) even commented that Swiss direct democracy was one of Switzerland's great exports. At the municipal level, direct democracy with respect to spatial planning manifests in at least two ways: first, community meetings where problems and proposed solutions are deliberated and voted upon by those present (usually an active minority who tend to be land-owning citizens who have lived in the area for a long time), and second, referendums in which Swiss citizens vote upon a given 'initiative'.

Clearly, municipalities are unable to administer or effect change beyond their jurisdictions and there is no formal requirement to interact or exchange with neighbouring entities. All inter-municipal interaction thus unfolds in the form of formal and informal negotiations. Here, as municipalities are small, this often follows personal or partisan networks (interviews with Real Estate Agent, March 2014 and May 2014; interviews with Government Officials March 2014 and June 2014). The Flughafenregion was formed in order to provide a platform for inter-municipal development and cooperation that did not exist previously. Not without conflict, the group has achieved a certain status in the area and regularly holds meetings for interested municipalities, residents, and other stakeholders. Proponents of this group tend also to support the notion of a 'Glatt Stadt', and perhaps, as one interviewee suggested, may comprise a unified political force to act as a counterweight to the City of Zurich (interview with Architects, February 2014).

As participative as the democratic structures may be, the role of the private sector cannot be overlooked as a central motor of local development. Since the majority of Glatt municipalities are sparsely staffed, infrastructural development is often contracted out to urbanists and real estate agents. One interview was even attended by both a local planner and a real estate developer, who sat together at the table to discuss local land use (March 2014), revealing that it is no secret that governing officials cooperate with private developers to carry out planning. The real estate developer also revealed that the networks he moves in - international real estate conferences, educational programmes for future real estate developers - play a central role in influencing how he carries out his work (interview Real Estate Developer, March 2014). A second dimension to the role of private actors is the attraction and establishment of businesses, which is an objective and activity of the Flughafenregion group (Lang 2014). Municipal officials were acutely aware of both their strategic location as well as the advantages of being small. Several interviewees commented that their municipalities were attractive for businesses because administrative pathways were considerably shorter, "like the difference between day and night" (interview with Real Estate Agent, May 2014). ${ }^{2}$

\subsection{The Mantra of Integrated Planning and Densification}

In this governance arrangement, densification, intensification, and integration were the strategies understood to deliver the desired transformation. Throughout the interviews, architects, urbanists, planners, real estate developers, and politicians were unanimous in the view that these approaches were the solution. This view of spatial planning was often rationalised as the result of ratified legal instruments that restrict the amount of building land, of the financial need to respond to subsidy programmes provided by upper layers of government, and of the desire to preserve green space and cultural heritage and simultaneously develop new housing opportunities and economic activity to ensure a constant flow of local tax revenue. It is worth noting that although the amount of developable land has not changed in nearly twenty years, land values have risen significantly (Tab. 2).

\section{Integrating Transport, Housing and Economic Activity in the Glatt Valley}

The effects of the specific constellation of spatial planning practices and governance is seen in the emerging set of intrinsic growth patterns in the Glatt Valley, most prominently visible in the new transport infrastructures, housing developments, and economic activities. Key is the integration of these sectors to generate not an urban region subordinate to (or dependent on) but rather competitive with (and independent from) the City of Zurich. In contrast to the normative tenets characteristic of integrative urban planning (recall Stead/Meijers 2009), the Glatt Valley is unfolding as a dynamic and fragmentary post-suburban space. While it is clear that transport infrastructures are understood to be a central component of successful sustainable urbanisation and that these can be developed in tandem with housing and economic growth, these successes have certain ramifications.

\subsection{Transport}

Transport infrastructure in the Glatt Valley was designed to reinforce existing functional pathways, as well as to attract and promote business investment and development. Having grown concurrently with Zurich during its emergence as a global financial centre (Diener/Herzog/Meili et al. 2006),

\footnotetext{
2 own translation ("ein Unterschied wie Tag und Nacht").
} 


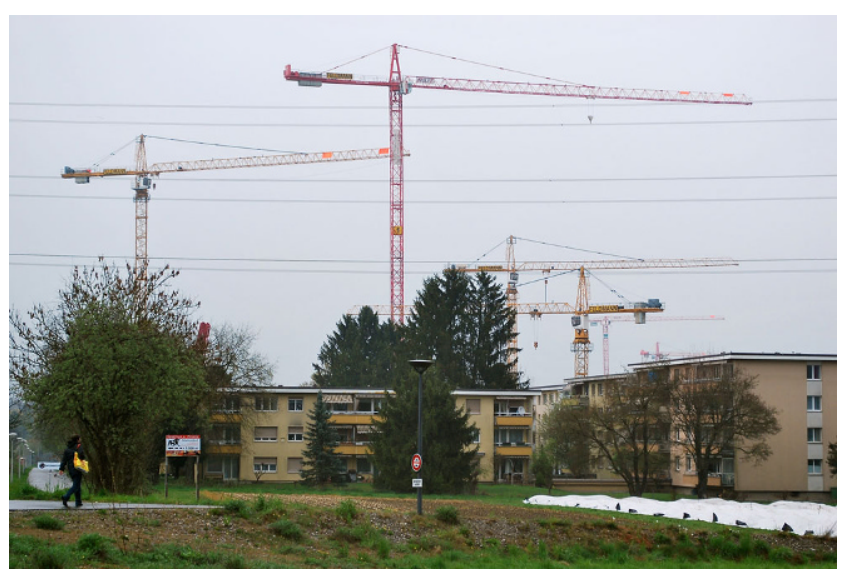

Fig. 2 Construction cranes rise above existing housing stock

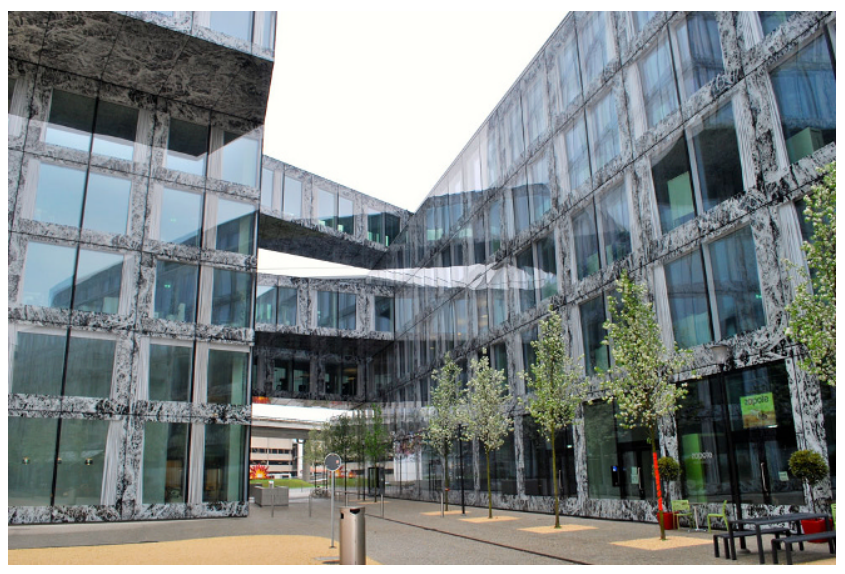

Fig. 3 New commercial development in Richti Wallisellen

Zurich Airport remains a major international hub with direct flights to 196 cities around the world serving over 25 million passengers per year (Flughafen Zürich 2015: 4). The airport has also been a significant engine of growth in the area (interviews, June 2014), and corporate headquarters and IT firms especially have established themselves in the large, mixed-use area of the Glatt Valley, rather than in Zurich, benefitting from the dual advantage of proximity to the growing airport and availability of land on which to develop (Diener/Herzog/Meili et al. 2006: 634). Thus, what some call a strategic 'airport corridor' between the airport and the City of Zurich has been created (Schaafsma 2010: 175), stretching through Glatt municipalities. Perhaps surprisingly, the airport has also promoted business growth in this area through effects such as aircraft noise, which has kept the price of land and office real estate here more competitive than elsewhere in the city-region, reinforcing a mutually beneficial growth dynamic between the airport and surrounding business areas (Salewski/Boucsein/Gasco 2015). The relationship between the airport and its residential neighbours, however, has led to considerable debate over flight paths. Following the termination of an agree- ment with the German government in 2003 over the use of air space over Germany to the north, the majority of flights now approach and depart from the airport over Switzerland and Zurich's more dense, built-up areas, leading to unresolved local and international tensions about aircraft noise (Scholl 2010). Although "restrictions on air traffic are already very tight and spatial planning has been intensively involved with the development of the airport" (Scholl/Nebel 2014: 66), a solution to the paradox of flight paths being concentrated over the expanding and densifying city-region has yet to be achieved.

Another transformational transport infrastructure project was the Glatt tram line, which extends from the City of Zurich to the airport. With financial assistance provided by the Agglomeration Programme and completed in 2010, it was built on derelict industrial sites with the intent to strengthen the 'airport region', winding through dense, productive areas across the Glatt municipalities towards the airport. The tram line was celebrated as a triumph of inter-municipal cooperation, for upgrading and revaluing the suburban neighbourhoods, and as a motor for economic activity. Salewski/Boucsein/Gasco (2015: 270) refer to the planning of the tram line as a process of "stitching together previous enclaves and islands". It is estimated that as a result of the tram, investment in the area is upwards of nine billion Swiss Francs (CHF), while the costs of its planning and construction was only 550 million (VBG 2009: 9). This success has encouraged other municipalities to join in and extend the line further outward, connecting outlying Glatt municipalities such as Bassersdorf or Wangen-Brüttisellen (VBG 2009; interviews with Municipal Officials, March and April 2014).

\subsection{Housing}

Touring the Glatt Valley, one is struck by the number of active construction cranes, reinforcing the image of the area as "Boom Town Switzerland" (Flughafenregion 2015: 2). Construction seems to be everywhere (Fig. 2). Many of these sites will become new apartment blocks - often using state-of-the-art building technology, contemporary architecture, and in some cases low-energy innovations, for example, the 2000-Watt apartment complex in Wallisellen built by one of the major developers active in the area, Allreal (Fig. 3). The average price for an apartment at the Richti Areal is 1.2 million Swiss Francs, clearly targeting highincome earners. It is also noteworthy that Allreal Holding AG, who operates solely within Switzerland, reports successful returns on investments from the sale of high-end apartment properties (with less success in rentals) (Allreal Holding 2014: 15). And, as a whole Holding reported that company profits rose $11 \%$ in 2013 compared to 2012 (Allreal Holding 2014: 59). 
Tab. 2 Land use in the Glatt region (Source: Kanton Zürich (2015))

\begin{tabular}{lll}
\hline Municipality & $\begin{array}{l}\text { Percentage increase or decrease in available building land } \\
(\text { bau perimeter }) \text { since } 1996(\%)\end{array}$ & $\begin{array}{l}\text { Percentage increase in the average value of } \\
\text { buildable land since } 1996(\%)\end{array}$ \\
\hline Bassersdorf & 0.02 & 40 \\
Dietlikon & 0.02 & 59 \\
Kloten & 0.42 & 12 \\
Opfikon & 0.00 & $79^{\mathrm{a}}$ \\
Wallisellen & 0.00 & $31^{\mathrm{a}}$ \\
Rümlang & 0.04 & 51 \\
Dübendorf & -0.01 & 69 \\
Wangen-Brüttisellen & 0.06 & 28 \\
\hline
\end{tabular}

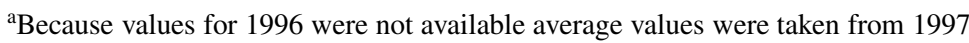

The design of new neighbourhoods is in contrast to the single-family housing districts in the hills or historical municipal centres that remain disconnected from the mixeduse, denser, public-transit corridors built in the flood zones. Many interviewees also confided that existing developments were not intended for local use. Rather, the goal of development is to provide housing infrastructure to attract new inhabitants and sustain economic activity that would, in turn, sustain pre-existing organisational modes: i.e. private property, municipal autonomy - two tenets held in high esteem among those interviewed. In this respect, the strategies have been very successful.

Some examples of socio-spatial polarisation can be identified as a result of this development strategy: first, single-family housing on one hand and labour on the other. There is a degree of ambivalence about where new employment areas should be located. Indeed, high-income earners can afford the new apartments - whose sale and profits circulate back to developers and their stakeholders. Major shareholders in Allreal Holding, for example, include (Allreal Holding 2014: 27): Helvetia Group, St. Gallen; BVK Employee Benefits and Pension Fund of the Canton Zurich; Pension Fund of Oerlikon Contraves AG; PKE-CPE ("The Leading Pension Fund of the Swiss Energy Branch"); Mobiliar Gruppe, Bern; Basellandschaft Pension Fund, Liestal. Lower-income earners, however, will have to choose longer commutes. Second, lifestyle divides between new urban apartment dwellers and older rural residents are being forged. One interviewee (Community Organiser, March 2014) commented that older residents tend to regard the newcomers with scepticism. Time is needed before full acceptance may be achieved. Third, and related: opinion leaders versus the disenfranchised. Several interviewees (Researcher February 2014, Government Official May 2014) remarked that turn-out at the community meetings was low, that it was always the same faces, and newcomers tended not to attend, leading to skewed democratic representation at local meetings, and a situation where opinion leaders were particularly powerful if they could convince the habitual voting population.

\subsection{Economic Activity}

Municipalities across Switzerland have a high degree of autonomy over local economic development, insofar as a high percentage of tax revenues from a given company flows directly back to the municipality. This inter-municipal tax competition is a topic of heated debate across Switzerland and is generally held to be one of the country's biggest unsolved problems. Some push for more cross-municipal tax compensation than the existing cantonal programmes for cross-municipal financial compensation (Zürcher Finanzausgleich) already achieve (Kanton Zürich 2011). Some point to the discrepancy between voting and tax competition. One interviewee (Architect, conducted in English, February 2014) complained: "A municipality will attract, say Nestle, and then it will be voted on whether or not a street should be built for it". Some municipalities "share' companies, e.g. Coca-Cola HBC Schweiz at the border between Wangen-Brüttisellen and Dietlikon. This is a position where perhaps both municipalities can profit (interview with Government Official March 2014).

An overview of the business development in the area is easily obtained from Flughafenregion (2015), whose explicit goal is "to develop the region in a positive manner taking advantage of its enthusiasm, sociability, warmth and bubbling energy. We constantly work to improve the area's attractiveness, workplaces and residential estates and to increase the standard of living. We strive to take the existing economic strength of our districts to further levels" (Flughafenregion 2015: 1).

Flughafenregion $(2015:$ 1) reports that in addition to the nine member municipalities, there are upwards of 120 member businesses. In 2012 alone, up to 1,000 new companies provided over 2,000 new jobs in the area. The Glatt Valley is now home to the headquarters of a number of international and Swiss businesses. The list of international 
corporations that have moved to the area includes Kraft, JSR, Hyatt, and Ecolab. Further, 300 of the 2,000 largest companies in Switzerland are located in the Glatt Valley.

Privileging the integration of places in the Glatt Valley and thus contributing to economic stability has led to several examples of increased polarisation. First, there is the conflict between those who want to preserve the rural character of the Glatt Valley versus those who embrace urbanisation. At one community meeting an elderly man stood up and loudly insisted that the trajectory of an urban Glatt Valley was not what he desired. He clearly wanted to retain his farming lifestyle. This was perhaps anecdotal, and a number of interviewees viewed this position as unrealistic, if not unusual these days (interviews with Government Official May 2014; interview with Planner June 2014), but it suggests that not everyone is convinced by the benefits of this strategy of local economic growth and that there is, at least, a certain nostalgia present in the communities. Second, there was an ambivalence about who would be the users of this new infrastructure. One interviewee (Government Official March 2014) remarked that they followed the advice of the developers, although to them it seems surprising that anyone would want to live in the newly built condominiums located in denser, noisier areas. Yet, as long as they sold and brought improvements to the municipality, then this interviewee could see no reason to argue against it. Third, there is the question of stronger versus weaker municipalities. Some municipal officials were sceptical of the 'Glatt City', seeing little advantage for their constituents, and claiming that some municipalities simply use the notion of an integrated Glatt Valley to promote local political and economic agendas, rather than a broader goal of sociospatial integration between municipalities.

\section{Integration in Swiss Post-suburban Growth}

The Glatt Valley, a blurry-edged space of overlapping flow and spaces of negotiation, spanning across an undefined number of small municipalities, is a useful addition to the catalogue of places that defy ongoing notions of suburbia. In fact, this fuzziness is one of the distinguishing characteristics of post-suburbia (Phelps/Wood/Valler 2010: 371). What is emerging in the Glatt Valley is neither a bounded dormitory district orienting around, nor a simple extension of, the City of Zurich. Rather, this ambiguous set of municipalities exhibits its own intrinsic transformation and, as some have observed elsewhere (KollSchretzenmayr/Schmid 2003), is at least attempting to upset the dominance of the City of Zurich. This article has additionally exposed some of the driving forces behind the Glatt Valley's development trajectory - namely, practices in integrative planning in combination with a certain con- stellation of governance. In this regard, the research differentiates itself from existing literature on post-suburbia, as it reveals contemporary post-suburbanisation processes in Switzerland that are place specific and path dependent. Furthermore, existing practices of integrated planning are not without their pitfalls. It would thus be prudent to further observe this development trajectory as new problems and challenges emerge.

There have been several attempts to categorise the various post-suburban forms. The tables of classification listed in the works of Charmes/Keil (2015: 595 f.), Phelps/Wood (2011: 2597) and Brenner/Schmid (2015: 171) are useful starting points here. Yet, locating development in the Glatt Valley on these tables is not easy. That new developments in the Glatt Valley target the upper classes, thus immediately excluding most of the categories listed by Charmes/ Keil (2015: 595 f.). The categories proposed by Phelps/ Wood (2011: 2597) define six settlement types but are also difficult to use as none of them correspond to the characteristics of state intervention, land use, and land ownership observed in the Glatt Valley, where a contentious state planning apparatus exists to regulate development. While there is significant room for private development to play a prominent role, new developments are approved by an electorate. The Glatt Valley thus provides the international literature with a new post-suburbia to struggle with.

A further point of entry into the analysis is the discussion of extended urbanism by Brenner/Schmid (2015). Their Lefebvrian account of spatial practices, territorial regulation and everyday life in extended urbanism is worth repeating: "Spatial practices [refer to] the activation of places, territories and landscapes in relation to agglomerations; the subsequent creation, thickening and stretching of an 'urban fabric' connecting agglomerations to the diverse sites of sociometabolic transformation upon which they depend. [...] Territorial regulation [refers to] governance systems oriented towards the sociometabolic and socioeconomic processes that support major urban centres and facilitate the thickening and stretching of an urban fabric across territories. [...] Everyday life refers to the social routines, everyday practices and forms of life that emerge (a) as diverse places, territories and landscapes are operationalized in relation to agglomerations, and (b) as a broader urban fabric is thickened and stretched across territories and scales" (Brenner/Schmid 2015: 171).

This idea encapsulates the notion of post-suburban transformation extending to the municipalities that are wedged between Zurich and the international airport and are confronted with opportunities and problems respective of this location. Ambiguous, however, is the degree to which the Glatt Valley can be construed as solely a space extending from Zurich, which is a view that might be construed as reaffirming the centrality and dominance of Zurich. In the 
same vein, Sieverts' (2003) in-between space (Zwischen$s t a d t)$ is equally dissatisfying. Clearly, in recent years, the Glatt Valley has revealed itself to be a multi-faceted area of activity, and indeed, there are links and interdependencies to the City of Zurich. However, the Glatt Valley harnesses activity beyond the City of Zurich, around the airport and Lake Greifen, it successfully competes for new private investment in various sectors, hosts thousands of labourers commuting to the region every day and receives funding from higher levels of government (via the Agglomeration Programme, for example) to construct infrastructure, and therefore can be seen to develop a variety of new spaces of flows and chains of dependencies that foster its development in its own right. The image of a suburb dependent on a centre is, thus, less and less appropriate.

As integrated spatial planning permeates all levels and spheres of land-use management and development in the Glatt Valley, this article can also comment on these literatures. Clearly, planners in the region aimed to integrate transportation, housing and economic activity - bounded by a limited land area - for the purpose of producing high-end residential and office space. Densification was the practical means of implementation, as new transportation infrastructure was intended to simultaneously integrate the airport and the City of Zurich, and connect the airport to the economic activity zones of the Glatt municipalities via the Glatt Tram - so named to reinforce the identity of the area. Contrary to the normative orientation that sustainable neighbourhoods will be produced by intensification, integration and densification, this dense, transit-oriented airport region benefitted private development through increasing property values along the path. And, as the Glatt Valley attracts a greater diversity of uses, drawing business, upper-class immigrants and a respective tax-base, the challenge to integrate such disparate functions using conventional spatial planning mechanisms becomes increasingly difficult. Emerging contradictions include transport disparities between high- and low-income wage earners, social conflicts between older and newer residents, and inter-municipal conflicts. Given these, one might call into question the appropriateness of existing planning structures to address such emerging post-suburban spaces. This recalls Graham/Marvin's (2001: 167) concept of a "global-local infrastructural bypass" which can occur, for example, between a city and its airport. The increasing socio-spatial polarisation of the Glatt Valley also confirms the work of Enright (2013), who highlighted the ways that a selective extension of infrastructures sparks new cycles of fragmentation. It also recalls Hesse's (2014) theory of "flawed urbanisation", suggesting that the incorporation of various elements into a so-called, all-encompassing whole - in the hopes of achieving socio-economic equity on a wider scale - can lead to a greater degree of fragmentation and con- tradiction. Transformation in the Glatt Valley shows that attempts to integrate land use, transport, and housing, can, in fact, reinforce fragmentation.

This transformation of the Glatt Valley is also a useful lesson in how current modes of growth in former urban peripheries work as transformation is steered by specific modes of local governance. The Glatt Valley is run by a collection of small municipalities, and this small state governance has several implications. There is an ambivalence as to who is really holding the reins of development: real estate developers and their investors or governing officials and the electorate? If it is the latter, then which governing bodies are most relevant, given the blurriness of the Glatt Valley's borders? Interviewees from both fields have commented how the smallness of Glatt Valley communities enables quicker development, faster profits and secured incomes. While the decisions of local government are regularly put to the electorate, the relationships between governing officials and the private sector, as well as the internal workings of development companies are clearly not. In this respect, one can speak of blended scales of activity, where "borders between different responsibilities and authorities are blurred and conflated, and where [...] agents take advantage (and disadvantage) of a converged or a mélange of scalar hierarchies to access and appropriate decisionmaking structures. This is seen when individuals occupy and take advantage of more than one position at one time, a condition that is fostered and exacerbated in a small state situation. It enables actors to harness converging spheres of governance, blur the boundaries between public and private interests, and override sector jurisdictions" (Affolderbach/ Carr 2016: 953).

As these authors argue, the system is open as actors can access different levels of decision-making. But, it is also closed because it is not obvious whether decisions were made through informal relations or democratic forums (Affolderbach/Carr 2016: 951). Thus, while it is clear that transformation in the Glatt Valley is not the result of the evacuation of the state, the role of private businesses and stakeholders remains ambiguous and significant as decision-makers in the region successfully attract capital and growth. Given this ultimately nebulous decision-making structure, one might again call into question the effectiveness of a spatial planning system that solely addresses nested governing hierarchies and nested jurisdictions.

The Glatt Valley is thus perhaps best understood through the lens of post-suburbanisation, and refocusing attention to the functions and productive forces that distinguish it. This type of observation has shown that transformation in the area is place-specific and path dependent. This not only demonstrates to the international literature that sets of problems and challenges are emerging and can be expected that differ from those observed in the Anglo-American sphere, 
but it is also a hint to Swiss decision-makers on how to address this area. New to the literature are the planning objectives, planning instruments, and the constellations of actors at work driving the process. Specifically, development in the Glatt Valley space is driven by practices of intensified development on existing land and the supposed coordination of economic activity, transport and housing in areas adjacent to the single-family housing districts that emerged 20 years ago. Indeed, the strategic promotion of this area as an airport region or 'Glatt City' reinforces and capitalises on the existing growth trajectories of the Glatt Valley to the benefit of higher-end commercial and residential development. This may be understandable within the logic of private, real estate development in the context of the growth pressures of the competitive global city-region. However, the emphasis on corporate office space and luxury living can be read as part of a process by urban governance to market and consolidate land on the urban periphery, moving towards the creation of internationally oriented pockets of privilege. It is clearly difficult for planning and associated governance structures not only to integrate or to create connectivity between the city centre, office parks and the airport, but also to integrate the new and existing fragmented, centreless places on the periphery with each other. Clearly, the Glatt Valley has become a crucial component in the continued urbanisation of the Zurich agglomeration and city-region. However, as urban activity extends beyond and into the north-eastern areas of Zurich's periphery, the Glatt Valley becomes more complex than 'suburb' would imply, and certainly more than simply Zurich's overflow area for new development. Instead, the uneven development across the Glatt Valley represents part of a broader process of the decentralisation of the urban fabric, opening up new challenges.

Acknowledgements The research upon which this paper is based was funded by the Fonds National de la Recherche Core program (project name: SUSTAIN_GOV). The authors gratefully acknowledge this support, and extend regards and thanks to the thoughtful comments of the reviewers that helped strengthen this paper.

\section{References}

Affolderbach, J.; Carr, C. (2016): Blending scales of governance: Land use policies and practices in the small state of Luxembourg. In: Regional Studies 50, 6, 944-955.

Allmendinger, P. (2009): Critical reflections on spatial planning. In: Environment and Planning A 41, 11, 2544-2549.

Allreal Holding AG (2014): Geschäftsbericht 2013. Baar.

Annaheim, H. (1969): Die Agglomeration von Basel und die Probleme der Raumplanung. In: Geographica Helvetica 24, 3, 99-103.

ARE - Bundesamt für Raumentwicklung (2015): Weisung über die Prüfung und Mitfinanzierung der Agglomerationsprogramme der dritten Generation. Bern.

Beatley, T. (2000): Green urbanism: Learning from European cities. Washington.
Bevir, M.; Rhodes, R. (2004): Interpreting British governance. In: British Journal of Politics and International Relations 6, 2, 130-136.

Bevir, M.; Rhodes, R. (2006): Governance stories. London.

Brenner, N.; Schmid, C. (2015): Towards a new epistemology of the urban? In: City 19, 2-3, 151-182.

Burdack, J.; Hesse, M. (2007): Suburbanisation, Suburbia and "Zwischenstadt": Perspectives of Research and Policy. In: Scholich, D. (ed.): Territorial Cohesion. Berlin, Heidelberg, New York, 81-100. = German Annual of Spatial Research and Policy 2007.

Carr, C. (2015): The power of sustainable development. In: Regions Magazine 300, 4, 11-13.

Carr, C.; Becker, T.; Evrard, E.; Nienaber, B.; Roos, U.; McDonough, E.; Hesse, M.; Krueger, R. (2015): Raising sustainability/ Mobilising sustainability: Why European sustainable urban development initiatives are slow to materialise/Territorial cohesion as a vehicle of sustainability/Sustainable urban development and the challenge of global air transport nodes and spatial integration/ Distorted density: Where developers and non-governmental organizations on sustainable urban development agree/Overcoming politics with markets? The co-production of sustainable development in urban and regional planning. In: Planning Theory \& Practice 16, 1, 99-125.

Carr, C.; McDonough, E.; Telaar, R. (2015): Integration als konzeptioneller Baustein und Widerspruch der nachhaltigen Raumplanung. In: Raumplanung 182, 6, 74-79.

Charmes, E.; Keil, R. (2015): The politics of post-suburban densification in Canada and France. In: International Journal of Urban and Regional Research 39, 3, 581-602.

Daum, M.; Schneeberger, P. (2013): Daheim - Eine Reise durch die Agglomeration. Zürich.

Diener, R.; Herzog, J.; Meili, M.; de Meuron, P.; Schmid, C. (2006): Switzerland. An Urban Portrait. Basel.

Enright, T.E. (2013): Mass transportation in the neoliberal city: The mobilizing myths of the Grand Paris Express. In: Environment and Planning A 45, 4, 797-813.

Faludi, A. (1970): The planning environment and the meaning of 'planning'. In: Regional Studies 4, 1, 1-9.

Fishman, R. (1987): Bourgeois utopias: The rise and fall of suburbia. New York.

Flughafen Zürich (2015): Zahlen und Fakten 2014. Zürich.

Flughafenregion Zürich (2013): Jahresbericht 2013. Zürich.

Flughafenregion Zürich (2015): Flughafenregion Zürich - the success location. Zürich. http://www.flughafenregion.ch/documents/ Fact_Sheet_English.pdf. (22.04.2016).

Garreau, J. (1991): Edge city: Life on the new frontier. New York.

Givoni, M.; MacMillen, J.; Banister, D.; Feitelson, E. (2013): From policy measures to policy packages. In: Transport Reviews 33, 1, $1-20$.

Graham, S.; Marvin, S. (2001): Splintering urbanism: networked infrastructures, technological mobilities and the urban condition. London.

Hesse, M. (2010): Suburbs: the next slum? Explorations into the contested terrain of social construction and political discourse. In: Articulo - Journal of Urban Research 3, 2-16.

Hesse, M. (2014): On borrowed size, flawed urbanisation and emerging enclave spaces: The exceptional urbanism of Luxembourg, Luxembourg. In: European Urban and Regional Studies 22, 5, 889-908.

Hesse, M.; Carr, C. (2013): Integration vs. fragmentation: spatial governance for land and mobility (extended abstract). In: Hesse, M.; Caruso, G.; Gerber, P.; Viti, F. (eds.): Proceedings of the BIVECGIBET Transport Research Days 2013. Zelzate, 379-383.

Heye, C.; Leuthold, H. (2006): Sozialräumlicher Wandel in der Agglomeration Zürich: Konsequenzen von Suburbanisierung und Reurbanisierung. In: disP - The Planning Review 42, 164, 16-29. 
Jackson, K.T. (1985): Crabgrass Frontier: The Suburbanization of the United States. New York.

Jacobs, J. (1961): The death and life of great American cities. New York.

Kanton Zürich (2011): Finanzausgleichgesetz (FAG) von 12. Juli 2010, Fragen aus der politischen Diskussion. Zürich.

Kanton Zürich (2014): Kantonaler Richtplan. Zürich. http://www. are.zh.ch/internet/baudirektion/are/de/raumplanung/kantonaler richtplan.html (22.04.2016).

Kanton Zürich (2015): Daten. Zürich. http://www.statistik.zh.ch/ internet/justiz inneres/statistik/de/daten.html (21.04.2016).

Kling, R.; Olin, S.; Poster, M. (1995): Postsuburban California. The Transformation of Orange County since World War II. Oakland.

Koll-Schretzenmayr, M.; Schmid, W.A. (2003): Agglomerationspolitik in der Schweiz: Einsichten und Ausblicke am Beispiel der "Glattal-Stadt". In: disP - The Planning Review 39, 152, 4-14.

Krueger, R.; Gibbs, D. (2012): Fractures in meta-narratives of development: An interpretive institutionalist account of land use development in the Boston city-region. In: International Journal of Urban and Regional Research 36, 2, 363-380.

Lang, C. (2014): Willkommen in der Flughafenregion Zürich - Die Wirtschaftsregion Nr. 1 der Schweiz. Zürich.

Lehrer, U.A. (1994): Images of the periphery: The architecture of Flex Space in Switzerland. In: Environment and Planning D 12, 2, 187-205.

Mace, A. (2013): City Suburbs: Placing Suburbia in a Post-suburban World. Hoboken.

Oswald, F.; Baccini, P.; Michaeli, M. (2003): Netzstadt. Designing the Urban. Basel.

Parker, S. (2004): Urban theory and the urban experience: Encountering the city. London.

Peck, J. (2011): Neoliberal suburbanism: Frontier Space. In: Urban Geography 32, 6, 884-919.

Phelps, N.A.; Wood, A.M.; Valler, D.C. (2010): A postuburban world? An outline of a research agenda In: Environment and Planning A 42, 2, 366-383.

Phelps, N.A.; Wood, A.M. (2011): The new post-suburban politics? In: Urban Studies 48, 12, 2591-2610.

Rowe, P.G. (1991): Making a middle landscape. Cambridge.
Salewski, C.; Boucsein, B.; Gasco, A. (2015): Towards an effect-based model for airports and cities. In: Conventz, S.; Thierstein, A. (eds.): Airports, Cities and Regions. London, 257-281.

Schaafsma, M. (2010): From airport city to airport corridor: Airport and city, sustainability and economy. In: Knippenberger, U.; Wall, A. (eds.): Airports in Cities and Regions. Research and Practise. Karlsruhe, 173-179.

Scholl, B. (2010): The interrelationships of airport and spatial development: Zurich Airport - Experiences from a test planning process. In: Knippenberger, U.; Wall, A. (eds.): Airports in Cities and Regions. Research and Practise. Karlsruhe, 127-136.

Scholl, B.; Nebel, R. (2014): Urban transformations in airport regions. In: disP - The Planning Review 50, 2, 65-75.

Schweizerischer Bundesrat (2012): Raumkonzept Schweiz. Bern.

Schweizerischer Bundesrat (2014): Botschaft zum Bundesbeschluss über die Freigabe der Mittel ab 2015 für das Programm Agglomerationsverkehr. Bern.

Sieverts, T. (2003): Cities without cities: An interpretation of the Zwischenstadt. London.

Soja, E.W. (2000): Postmetropolis. Oxford.

Soja, E.W. (2011): Regional urbanization and the end of the metropolis era. In: Bridge, G.; Watson, S. (eds.): The New Blackwell Companion to the City. Hoboken, 679-689.

Stead, D.; Meijers, E. (2009): Spatial planning and policy integration: Concepts, facilitators, and inhibitors. In: Planning Theory and Practice 10, 3, 317-332.

Storper, M. (2014): Governing the large metropolis. In: Territory, Politics, Governance 2, 2, 115-134.

Sudjic, D. (1992): The 100 mile city. London.

Thierstein, A.; Kruse, C.; Glanzmann, L.; Gabi, S.; Grillon, N. (2006): Raumentwicklung im Verborgenen. Zürich.

VBG - Verkehrsbetrieb Glattal (2009): Die Glattalbahn: Bewegung im urbanen Lebensraum. Glattbrugg.

Wachsmuth, D. (2014): City as ideology: Reconciling the explosion of the city form with the tenacity of the city concept. In: Environment and Planning D 32, 1, 75-90.

Young, D.; Keil, R. (2010): Reconnecting the disconnected: The politics of infrastructure in the in-between city. In: Cities 27, 2, $87-95$. 